Trinity University

Digital Commons@ Trinity

Biology Faculty Research

Biology Department

2012

\title{
Carotenoid-Based Ornaments of Female and Male American Goldfinches (Spinus tristis) Show Sex- Specific Correlations with Immune Function and Metabolic Rate
}

R.J. Kelly

Troy G. Murphy

TrinityUniversity, tmurphy@trinity.edu

K.A. Tarvin

G. Burness

Follow this and additional works at: https://digitalcommons.trinity.edu/bio_faculty

Part of the Biology Commons

\section{Repository Citation}

Murphy T. G., Tarvin K. A., and Burness G. (2012) Carotenoid-based ornaments of female and male American goldfinches (Spinus tristis) show sex-specific correlations with immune function and metabolic rate. Physiological and Biochemical Zoology 85(4), 348-363. doi:10.1086/666059 


\section{Carotenoid-Based Ornaments of Female and Male American Goldfinches (Spinus tristis) Show Sex-Specific Correlations with Immune Function and Metabolic Rate}

\author{
Ryan J. Kelly ${ }^{1, *}$ \\ Troy G. Murphy ${ }^{2, \star, \dagger}$ \\ Keith A. Tarvin ${ }^{3}$ \\ Gary Burness ${ }^{1,}$ \\ ${ }^{1}$ Department of Biology, Trent University, Peterborough, \\ Ontario K9J 7B8, Canada; ${ }^{2}$ Department of Biology, Queen's \\ University, Kingston, Ontario K7L 3N6, Canada; \\ ${ }^{3}$ Department of Biology, Oberlin College, Oberlin, Ohio 44074
}

Accepted 3/28/2012; Electronically Published 6/7/2012

\begin{abstract}
Conspicuous ornamentation has been linked to immunological and physiological condition in males of many species. In species where both sexes are ornamented, it is unclear whether the signal content of ornaments differs between males and females. We examined the immunological and physiological correlates of carotenoid-based bill and plumage ornamentation in American goldfinches Spinus tristis, a species in which bright orange bills are sexually monomorphic but yellow plumage is sexually dimorphic during the breeding season. Because bill color is dynamic over short periods while plumage color is static over longer time frames, we tested whether these signals have the potential to provide temporal information about immunity and condition. In both sexes, bill color (but not plumage color) was negatively related to leukocyte differential, a measure of recent stress, while plumage color (but not bill color) was positively related to resting metabolic rate. In females, bill color also positively correlated with immunoglobulin $\mathrm{Y}$, a component of acquired immunity, while plumage color positively predicted natural antibody levels, a component of innate immunity. In males, neither bill color nor plumage color predicted immune function, suggesting that the mechanisms underlying these signals vary with sex. Our results demonstrate that dynamic signals such as bill coloration do not merely reflect the same information provided by static signals but that these two classes of
\end{abstract}

\footnotetext{
* These authors contributed equally to this work.

${ }^{\dagger}$ Present address: Department of Biology, Trinity University, San Antonio, Texas 78212.

${ }^{\ddagger}$ Corresponding author; e-mail: garyburness@trentu.ca.
}

Physiological and Biochemical Zoology 85(4):348-363. 2012. (C) 2012 by The University of Chicago. All rights reserved. 1522-2152/2012/8504-2007\$15.00. DOI: $10.1086 / 666059$ signal provide information about different temporal aspects of phenotypic quality. Furthermore, our results indicate that a signal expressed in both sexes has the potential to provide different information depending on the sex of the bearer.

\section{Introduction}

In many animals, males display conspicuous ornamentation, and the most elaborate males achieve the highest mating success (Andersson 1994). Extensive evidence supports a link between male signal strength and indexes of immunity across a wide variety of taxa, including birds (e.g., Dufva and Allander 1995; Doucet and Montgomerie 2003; Faivre et al. 2003; McGraw and Ardia 2003; Dunn et al. 2010), fish (Clotfelter et al. 2007), and lizards (Martín and López 2009). There is increasing evidence that elaborate female traits also confer a selective advantage during inter- or intrasexual interactions (see Amundsen 2000; LeBas 2006; Clutton-Brock 2009). Female ornaments have been found to signal immune function (but see Pärn et al. 2005), yet most studies on females have focused on species in which ornamental expression is limited to or more pronounced in females (Roulin et al. 2001a, 2001b; Hanssen et al. 2006). In contrast, few studies have examined whether ornaments shared by the sexes signal the same or different aspects of immunity or physiological condition (but see Alvarez et al. 2005; Lopez et al. 2008; Maney et al. 2008). The observation that males and females of a species often differ in immunocompetence (e.g., Nunn et al. 2009; Pap et al. 2010) raises the question of whether ornamentation shared by the sexes reflects immune function in the same way in both sexes. Given that ornaments may be maintained by different selective forces acting on each sex (Heinsohn et al. 2005; LeBas 2006; Murphy 2006, 2007; Murphy et al. 2009), we might expect the information signaled by ornaments to differ between males and females.

The vertebrate immune system can be broadly divided into innate and acquired (or adaptive) immunity components (e.g., Demas et al. 2011). The innate immune system provides the first line of defense against infection and contributes to rapid nonspecific protection against invading pathogens through both humoral and cellular components. The acquired immune system is divided into humoral and cell-mediated immunity and initiates slower responses that target specific infectious agents, providing long-lasting protection against bacteria, vi- 
ruses, fungi, and other parasites. Increasingly, researchers recognize that in order to gain a more complete understanding of an individual animal's immunocompetence, it is necessary to assess components of innate and acquired arms simultaneously, because allocation to one arm of the immune system may or may not be correlated with allocation to the other (Norris and Evans 2000; Saks et al. 2003; Hõrak et al. 2006; Buehler et al. 2008). Thus, investment in innate versus acquired immunity may vary with sex, age, or investment in other lifehistory traits (Martin et al. 2007; Ardia et al. 2011). As such, the two different arms may provide contrasting views of the relationship between ornamentation and immune function, and in cases where an ornament is shared by the sexes, it seems plausible that the ornament may signal different components of immunity in males and females.

Carotenoid-based ornamentation often signals immunocompetence (e.g., Saks et al. 2003; Aguilera and Amat 2007; Baeta et al. 2008; Dunn et al. 2010). Increased intake of dietary carotenoids has been associated with various immune function benefits, including increased cell-mediated and humoral immune responsiveness and decreased DNA damage and inflammation (e.g., Chew et al. 2011). However, the specific effects of carotenoids on the immune response vary with type of carotenoid, dosage, and species studied (Chew and Park 2004). Links between carotenoids and health benefits are likely due to their antioxidant properties, although other mechanisms, including gap junction communication and regulation of membrane fluidity, are also likely involved (Chew and Park 2004; Rao and Rao 2007). Carotenoid-based ornaments may thus allow an individual to signal health because allocation of carotenoids to ornamentation can occur only if carotenoids are not being used elsewhere (e.g., Lozano 1994; Møller et al. 2000; but see Costantini and Møller 2008). Alternatively, carotenoid ornamentation may be correlated with immune function because both are dependent on the functionality of a common set of biochemical pathways that are themselves dependent on individual condition (reviewed by Hill 2011). Regardless of the underlying mechanism, these hypotheses predict that carotenoid ornamentation should reliably signal immunocompetence.

Immune function has also been linked with mass-adjusted basal (or resting) metabolic rate (Tieleman et al. 2005), although this relationship is complex (see Martin et al. 2007; Tieleman et al. 2008). Among species, variation in resting metabolic rate (RMR) reflects the "pace of life" such that species that tend to invest in survival over current reproduction tend to have lower RMR (Tieleman et al. 2005; Wiersma et al. 2007). However, among individuals within a species, RMR may indicate an individual's capacity to perform well during challenging activities (e.g., Biro and Stamps 2010). For example, some components of immune function, such as constitutive innate immunity, have been found to positively relate to massadjusted RMR within a species (Tieleman et al. 2005). Additionally, experimental activation of the immune system can lead to an elevation in RMR, presumably to fuel the costs of the immune activity (e.g., Burness et al. 2010; Van de Crommen- acker et al. 2010). Individuals in higher condition should be able to expend more energy toward both immunity and ornamentation, so we expect high-quality individuals to be able to sustain both high RMR and high ornamentation.

In this study we examined the immunological and metabolic correlates of carotenoid-based bill and plumage ornamentation in male and female American goldfinches Spinus tristis. In this species, both males and females express a common set of ornaments, but their ornaments appear to function as communication signals in different social contexts. Orange bill coloration, which is expressed similarly in the sexes, functions in females as a signal of status during competitive interactions with other females (Murphy et al. 2009), while male bill color does not appear to play a signaling role in the same competitive context (T. G. Murphy and K. A. Tarvin, unpublished data). Moreover, experimental manipulations of bill color indicate that it does not play a role in mate choice in either sex (T. G. Murphy and K. A. Tarvin, unpublished data). A second conspicuous ornament is the saturated yellow plumage, which is more pronounced in males. Male plumage color functions as a mate-choice signal: in an aviary mate-choice trial, Johnson et al. (1993) found that females preferred males with darker throat plumage (i.e., lower luminance). In contrast, the function of female plumage color remains unknown. However, based on findings of assortative mating with respect to plumage color saturation (MacDougall and Montgomerie 2003), female plumage may also function as a mate-choice signal. In addition to playing different roles in communication, these two ornaments vary in an important way: bill coloration has been found to change rapidly, in a matter of hours, under experimentally induced physiological perturbations in both sexes (Rosen and Tarvin 2006; M. F. Rosenthal, T. G. Murphy, N. Darling, and K. A. Tarvin, unpublished data), whereas plumage color changes little between the molt in early spring, when they acquire breeding plumage, and the loss of their colorful feathers after the breeding season. Thus, dynamic bill color has the potential to reflect current physiological state, whereas static plumage color can reflect only condition at the time of molt.

We hypothesize that bill and plumage color are conditiondependent signals in both sexes and that dynamic bill color reflects aspects of condition that fluctuate over a short time frame whereas static plumage color reflects less labile components of condition. Furthermore, based on the different roles these ornaments appear to play in male and female communication (Johnson et al. 1993; Murphy et al. 2009), we explore the possibility that these shared ornaments communicate different aspects of immunity and condition in males and females. If the ornaments do indeed have sex-specific roles in signaling, it seems possible that differences exist between the sexes in what the ornaments reflect; however, it is also possible that the ornaments reflect the same component of condition in both sexes and that receivers respond to the ornaments in a sexspecific manner (e.g., disregarding information conveyed in a signal if given by one sex while assessing it in the other sex). Because both are plausible explanations, we make no directional predictions about sex differences and simply predict that highly 
ornamented goldfinches (of both sexes) will have lower stress, higher RMR, and more robust innate and adaptive immune systems. We measured stress based on the ratio of heterophils to lymphocytes $(\mathrm{H}: \mathrm{L})$ in whole blood because high ratios of these immunologically important leukocytes are indicative of stress and have been positively correlated with susceptibility to infection and negatively correlated with growth rate and survival (reviewed in Davis et al. 2008; see also Müller et al. 2011). We additionally test the prediction that ornamental coloration is positively correlated with RMR because individuals with higher RMR are expected to have a greater capacity to engage in energetically costly activities (e.g., parental care, competitive interactions). To assess immunity, we measured levels of natural antibodies (NAb) and immunoglobulins (IgY). NAb, a component of the innate humoral immune system, bind to foreign antigens and neutralize infection (Ochsenbein and Zinkernagel 2000). IgY, a component of the adaptive humoral immune system, is the most abundant class of antibodies in avian blood and on infection coats microorganisms, allowing other immune cells to recognize and destroy them (Demas et al. 2011).

\section{Material and Methods}

\section{Species}

Both male and female American goldfinches develop vibrant orange bills and moult into colorful yellow plumage before the onset of the breeding season. Although bill color is very similar in the two sexes, their plumage is markedly sexually dichromatic: the yellow plumage of males covers much of the body whereas that of females tends to be drabber and occurs in small patches, though the size of the patches is highly variable (Rosen and Tarvin 2006; McGraw and Middleton 2009).

In previous research, we found that bill color of wild male and female goldfinches held in captivity significantly declined within $7 \mathrm{~h}$ of capture (presumably because of stress of captivity). The decline continued over several days and was significantly greater among birds (males and females) that were exposed to an experimental immune challenge (M. F. Rosenthal, T. G. Murphy, N. Darling, and K. A. Tarvin, unpublished data). Thus, bill color is dynamic over short time periods, and fluctuations in bill color appear to correspond with short-term changes in physiological condition.

\section{General Methods}

We captured 41 male and 28 female American goldfinches in July 2008 at Queens University Biological Station in Ontario, Canada $\left(44^{\circ} 33^{\prime} \mathrm{N}, 76^{\circ} 19^{\prime} \mathrm{W}\right)$. Goldfinches were captured with mist nets placed around feeders at three different sites within a $15-\mathrm{km}$ radius. On capture, we categorized sex and age class (in their second calendar year [SY]-i.e., hatched the previous summer-and after their second year [ASY]) based on plumage (Pyle 1997), measured mass ( $\pm 0.1 \mathrm{~g}$ ), and morphological features $( \pm 0.1 \mathrm{~mm})$ and collected ca. $100 \mu \mathrm{L}$ of blood. Blood was collected from the brachial wing vein into two heparinized capillary tubes, sealed with clay, and stored up to $4 \mathrm{~h}$ on ice until processing. An additional drop of blood was collected into a nonheparinized capillary tube and used to make two blood smears following Davis (2005). Slides were air-dried and stored until staining took place. Blood samples were centrifuged (Hemata STAT-II, Separation Technology) for three 60-s intervals. Plasma was removed, placed into microcentrifuge tubes, and frozen at $-20^{\circ} \mathrm{C}$ for up to $4 \mathrm{wk}$. Samples were then transferred to a $-80^{\circ} \mathrm{C}$ freezer until analysis.

Because bill color is dynamic and changes rapidly in this species in response to stress of capture (Rosen and Tarvin 2006; M. F. Rosenthal, T. G. Murphy, N. Darling, and K. A. Tarvin, unpublished data), we measured color reflectance $(R)$ of the bill within $1 \mathrm{~h}$ of capture (mean $\pm \mathrm{SE}=32.1 \pm 2.7 \mathrm{~min}$ ), which is a few hours before stress-induced color change has been detected spectrometrically (M. F. Rosenthal, T. G. Murphy, N. Darling, and K. A. Tarvin, unpublished data). Individuals were then transported to the biological station and placed in visually isolated housing units $\left(1.2 \mathrm{~m}^{3}\right)$ for ca. $6 \mathrm{~h}$, where they received water and Nyjer seed ad lib. On the same evening of capture, up to three birds were placed into individual metabolic chambers where oxygen consumption was measured overnight as an index of RMR. After RMR was measured, birds were used in a dominance experiment the next morning (see Murphy et al. 2009) and released at their capture site. Only adult (ASY) birds were used for this experiment. All research was conducted under Queen's University animal care protocol 2005-044 and Trent University protocol 08046.

\section{Color Analysis}

We collected spectral measures from the bill and throat of each bird. We used an Ocean Optics USB2000+ spectrometer and a PX-2 pulsed xenon lamp (Ocean Optics, Dunedin, FL) with the probe held at $90^{\circ}$ to the color patch. The probe was fixed within a dark plastic holder, which held the probe tip approximately $7 \mathrm{~mm}$ from the color patch. We quantified $R$ as the proportion of light reflected from the color patch compared with a Spectralon white standard (Labsphere) at 1-nm intervals across the avian visual range $(320-700 \mathrm{~nm})$. We calculated the mean $R$ of five measures for each color patch, each taken at a different haphazardly chosen location within a color patch. Using mean $R$ curves, we calculated mean luminance ("brightness"; mean $R$ from 320 to $700 \mathrm{~nm}$ ); hue, a measure of spectral location (wavelength where $R=\left[R_{\max }+R_{\min }\right] / 2$ ); and yellow saturation, a measure of spectral purity (sum of $R$ from 550 to $625 \mathrm{~nm} /$ mean luminance) using CLR 1.05 (Montgomerie 2008; see table 3.2 in Montgomerie 2006 for further details). These color analysis techniques are standard for carotenoidbased traits (Montgomerie 2008) and are similar to those used in other studies of goldfinches (MacDougall and Montgomerie 2003; Hill et al. 2009). All color measures were taken by T.G.M.

\section{Natural Antibody Levels}

Innate humoral immunity was measured by quantifying NAb and complement in each individual's plasma following Matson 
Table 1: Color and physiological parameters of male and female American goldfinches

\begin{tabular}{|c|c|c|c|c|c|c|}
\hline \multirow[b]{2}{*}{ Variable bill luminance } & \multicolumn{2}{|c|}{ Mean \pm SE $(n)$} & \multicolumn{2}{|c|}{ Capture date } & \multicolumn{2}{|c|}{ Sex } \\
\hline & Males & Females & $F$ & $P$ & $F$ & $P$ \\
\hline Bill luminance & $.266 \pm .007(32)$ & $.222 \pm .008(25)$ & .64 & .426 & 16.79 & $<.001$ \\
\hline Bill saturation & $.248 \pm .001(32)$ & $.246 \pm .002(25)$ & 2.69 & .107 & 1.81 & .184 \\
\hline Bill hue & $550.1 \pm .957(32)$ & $546.2 \pm 1.085$ & 23.81 & $<.001$ & 7.23 & .010 \\
\hline Throat luminance & $.302 \pm .005(32)$ & $.260 \pm .006(25)$ & 6.92 & .011 & 31.18 & $<.001$ \\
\hline Throat saturation & $.324 \pm .002(32)$ & $.300 \pm .003(25)$ & 17.02 & $<.001$ & 44.81 & $<.001$ \\
\hline Throat hue & $505.7 \pm .454(32)$ & $501.0 \pm .515(25)$ & 11.80 & .001 & 46.42 & $<.001$ \\
\hline $\operatorname{IgY}$ & $.148 \pm .007(24)$ & $.171 \pm .007(20)$ & 1.28 & .265 & 6.11 & .018 \\
\hline $\mathrm{NAb}$ & $1.191 \pm .123(19)$ & $1.745 \pm .126(18)$ & 7.75 & .009 & 9.69 & .004 \\
\hline $\mathrm{H}: \mathrm{L}$ ratio & $.768 \pm .076(28)$ & $.579 \pm .065(22)$ & 1.44 & .236 & 2.44 & .125 \\
\hline $\mathrm{RMR}^{\mathrm{a}}$ & $43.910 \pm .673(24)$ & $43.510 \pm .793(18)$ & .01 & .926 & .13 & .719 \\
\hline
\end{tabular}

Note. Estimated marginal means and standard errors are presented when the effect of capture date was significant. Unadjusted means and standard errors are presented otherwise. IgY = immunoglobulin $\mathrm{Y} ; \mathrm{NAb}=$ natural antibodies; $\mathrm{H}: \mathrm{L}$ ratio $=$ heterophil-tolymphocyte ratio; $\mathrm{RMR}=$ resting metabolic rate.

${ }^{\mathrm{a}}$ Estimated marginal means and standard error adjusted for effect of mass: $F=31.81, P<0.001$.

et al. (2005). Because complement was detected for only a single individual, we do not discuss complement further. NAb titers were obtained for 37 adults (19 males, 18 females). Intra- and interplate assay variation for hemagglutination assays (obtained from two control samples run on each assay plate) was $3.3 \%$ and $2.5 \%$, respectively. The assay and scoring were performed blindly by R.J.K.
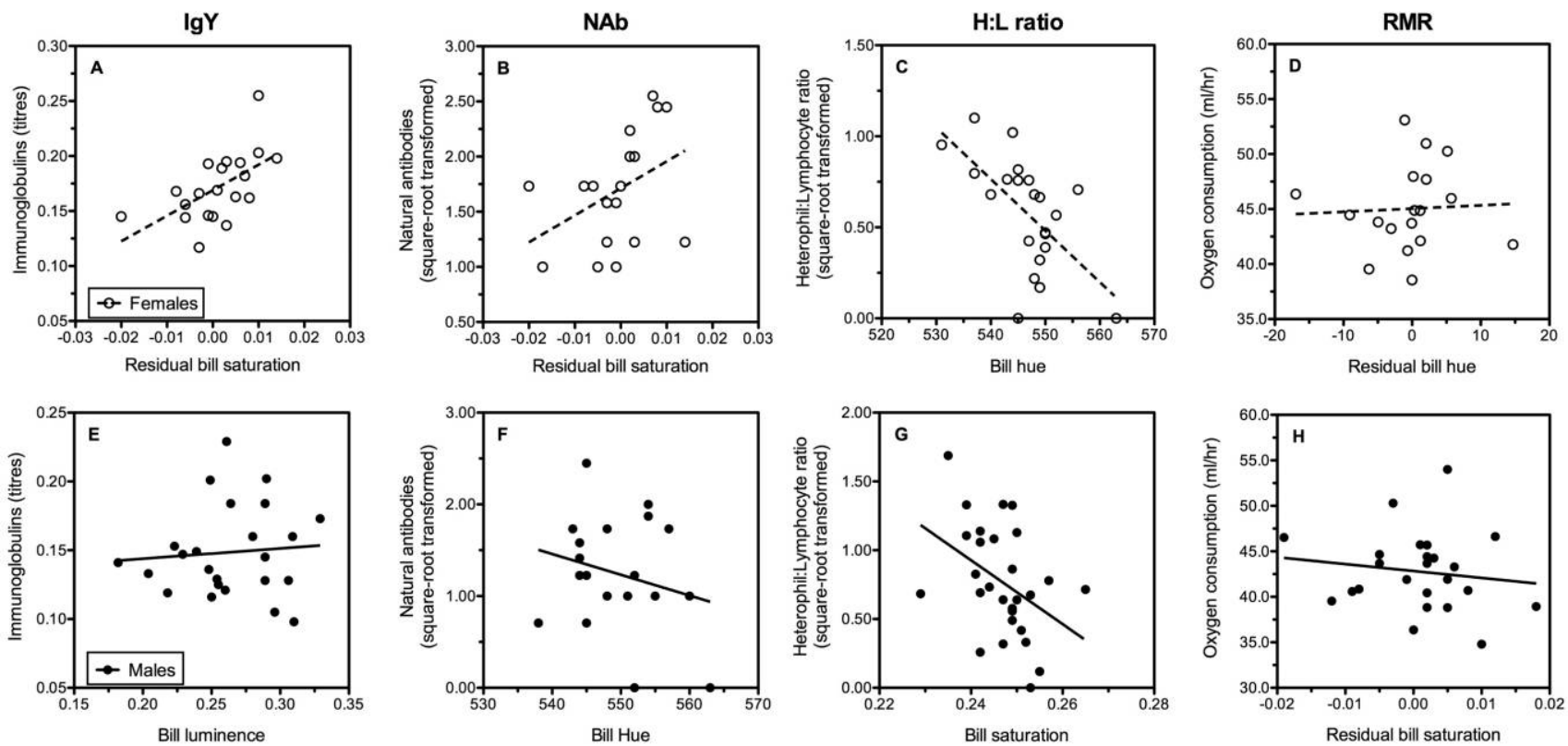

Figure 1. Bill coloration in relation to physiology and immunology of female and male American goldfinches. The independent variable represents the best model of the set that contained a color variable. Note that the best model may have had similar support to a model containing only the intercept (see text for description of best models). Fitted lines are to aid in visual interpretation of patterns. Figures show residuals when the top model included two or more independent variables. Residuals in $A$ and $B$ controlled for the effect of capture date, while $D$ and $H$ controlled for the effect of body mass on the color variable of interest. IgY = immunoglobulin Y; NAb = natural antibodies; $\mathrm{H}: \mathrm{L}$ ratio $=$ heterophil-to-lymphocyte ratio; $\mathrm{RMR}=$ resting metabolic rate. 
Table 2: $95 \%$ confidence set of best-ranked regression models explaining variation in female bill color

\begin{tabular}{|c|c|c|c|c|c|c|}
\hline Model & $K$ & AICc & $\Delta \mathrm{AICc}$ & $W_{\mathrm{i}}$ & $\operatorname{Acc} W_{\mathrm{i}}$ & ER \\
\hline \multicolumn{7}{|l|}{ IgY: } \\
\hline Saturation + date & 4 & -141.567 & .000 & .395 & .395 & $\ldots$ \\
\hline Saturation & 3 & -140.639 & .928 & .248 & .643 & 1.59 \\
\hline Saturation + mass + date & 5 & -137.964 & 3.603 & .065 & .708 & 6.06 \\
\hline Saturation + mass & 4 & -137.640 & 3.927 & .055 & .763 & 7.13 \\
\hline Luminance & 3 & -137.433 & 4.134 & .050 & .813 & 7.90 \\
\hline Intercept only & 2 & -137.404 & 4.163 & .049 & .862 & 8.02 \\
\hline Luminance + date & 4 & -136.784 & 4.783 & .036 & .898 & 10.93 \\
\hline Date & 3 & -135.713 & 5.854 & .021 & .920 & 18.67 \\
\hline Mass & 3 & -135.247 & 6.321 & .017 & .936 & 23.58 \\
\hline \multicolumn{7}{|l|}{ NAb: } \\
\hline Saturation + date & 4 & -25.821 & .000 & .335 & .335 & $\ldots$ \\
\hline Date & 3 & -24.156 & 1.665 & .146 & .481 & 2.30 \\
\hline Mass & 3 & -23.040 & 2.781 & .083 & .564 & 4.02 \\
\hline Saturation + mass + date & 5 & -22.708 & 3.113 & .071 & .635 & 4.74 \\
\hline Date + mass & 4 & -22.316 & 3.505 & .058 & .693 & 5.77 \\
\hline Intercept only & 2 & -22.188 & 3.633 & .054 & .747 & 6.15 \\
\hline Luminance + date & 4 & -21.969 & 3.852 & .049 & .796 & 6.86 \\
\hline Hue & 3 & -21.693 & 4.128 & .043 & .839 & 7.88 \\
\hline Saturation + mass & 4 & -21.066 & 4.755 & .031 & .870 & 10.78 \\
\hline Hue + date & 4 & -20.814 & 5.007 & .027 & .897 & 12.23 \\
\hline Hue + mass & 4 & -20.792 & 5.029 & .027 & .924 & 12.36 \\
\hline Saturation & 3 & -20.657 & 5.164 & .025 & .950 & 13.22 \\
\hline \multicolumn{7}{|l|}{$\mathrm{H}: \mathrm{L}$ ratio: } \\
\hline Hue & 3 & -58.341 & .000 & .467 & .467 & $\ldots$ \\
\hline Hue + mass & 4 & -57.188 & 1.154 & .262 & .730 & 1.78 \\
\hline Hue + date & 4 & -55.504 & 2.838 & .113 & .843 & 4.13 \\
\hline Hue + mass + date & 5 & -54.539 & 3.803 & .070 & .912 & 6.69 \\
\hline Date & 3 & -52.156 & 6.186 & .021 & .934 & 22.04 \\
\hline Luminance + date & 4 & -51.417 & 6.925 & .015 & .948 & 31.89 \\
\hline \multicolumn{7}{|l|}{ RMR: } \\
\hline Mass & 3 & 37.030 & .000 & .484 & .484 & $\cdots$ \\
\hline Date + mass & 4 & 39.271 & 2.241 & .158 & .642 & 3.07 \\
\hline Hue + mass & 4 & 40.179 & 3.149 & .100 & .742 & 4.83 \\
\hline Saturation + mass & 4 & 40.325 & 3.295 & .093 & .835 & 5.19 \\
\hline Luminance + mass & 4 & 40.383 & 3.352 & .091 & .926 & 5.34 \\
\hline
\end{tabular}

Note. $\mathrm{IgY}=$ immunoglobulin $\mathrm{Y} ; \mathrm{NAb}=$ natural antibodies; RMR $=$ resting metabolic rate; $\mathrm{H}: \mathrm{L}$ ratio $=$ heterophil-to-leukocyte ratio; $K=$ parameters in the model; AICc $=$ corrected Akaike Information Criterion; $\triangle \mathrm{AICc}=$ difference in AICc score between focal model and best model; $W_{\mathrm{i}}=$ Akaike weight; Acc $W_{\mathrm{i}}=$ accumulated Akaike weight; $\mathrm{ER}=$ evidence ratio.

and the mean IgY absorbance value was used in analysis. The average coefficient of variation (CV) between duplicate samples was $4.96 \%$, and no sample with a CV of more than 15 was used in analysis. IgY absorbance values were obtained for 44 individuals (24 males, 20 females).

\section{$H: L$ Ratio}

Two blood smears were made within $1 \mathrm{~h}$ of capture for each individual. Blood smears were stained using Diff-Quik Stain
Set (Dade Behring, Newark, DE). Heterophils and lymphocytes were counted under oil immersion at 1,000 $\times$ magnification until 100 leukocytes were identified or 150 fields of a homogenous monolayer of cells had been examined, whichever came first, following Maney et al. (2008). Because smears were of varying quality, all blood smears were initially ranked blindly (by R.J.K.) based on gross appearance (quality of the shape and staining of the smear) and assigned a score of 1-4 (from low to high quality). When two high-quality blood smears were available, we averaged the $\mathrm{H}$ : $\mathrm{L}$ ratio for the two slides; oth- 
Table 3: Full-model-averaged estimates for each variable in the global model predicting female bill color

\begin{tabular}{|c|c|c|c|}
\hline $\begin{array}{l}\text { Response and } \\
\text { predictor variables }\end{array}$ & $W$ & $\tilde{\bar{\beta}}$ & $\operatorname{Var}(\tilde{\bar{\beta}})$ \\
\hline \multicolumn{4}{|l|}{ IgY: } \\
\hline Intercept & $\ldots$ & -.5255 & 2.1069 \\
\hline Date & .548 & .0013 & $1.9 \times 10^{-5}$ \\
\hline Mass & .170 & .0004 & .0003 \\
\hline Luminance & .104 & -.0342 & .0833 \\
\hline Saturation & .763 & 1.6710 & 9.9833 \\
\hline Hue & .040 & $5.6 \times 10^{-5}$ & $1.3 \times 10^{-6}$ \\
\hline \multicolumn{4}{|l|}{ NAb: } \\
\hline Intercept & $\ldots$ & -8.0297 & 632.8369 \\
\hline Date & .703 & .0351 & .0059 \\
\hline Mass & .304 & .0689 & .1584 \\
\hline Luminance & .091 & -.1684 & 15.6230 \\
\hline Saturation & .462 & 11.1598 & $1,350.5058$ \\
\hline Hue & .105 & -.0015 & .0006 \\
\hline \multicolumn{4}{|l|}{ H : L ratio: } \\
\hline Intercept & $\cdots$ & 14.6153 & 577.5950 \\
\hline Date & .243 & .0028 & .0009 \\
\hline Mass & .356 & -.0347 & .0469 \\
\hline Luminance & .027 & .0636 & 1.9431 \\
\hline Saturation & .015 & -.0979 & 20.3558 \\
\hline Hue & .912 & -.0256 & .0015 \\
\hline \multicolumn{4}{|l|}{ RMR: } \\
\hline Intercept & $\ldots$ & -7.6750 & $14,746.0040$ \\
\hline Date & .230 & -.0274 & .0653 \\
\hline Mass & .998 & 4.3035 & 15.1264 \\
\hline Luminance & .117 & .3660 & 655.9392 \\
\hline Saturation & .116 & 2.2525 & $21,274.2910$ \\
\hline Hue & .124 & .0031 & .0248 \\
\hline
\end{tabular}

erwise, we analyzed the slide of the highest quality. The $\mathrm{H}: \mathrm{L}$ ratio was measured for 50 individuals ( 28 males, 22 females). Sample sizes were larger for the $\mathrm{H}: \mathrm{L}$ ratio than for NAb and IgY because blood smears were collected in the field, and blood samples were not always sufficiently large to run all remaining assays.

\section{$R M R$}

Birds were retrieved from the outdoor aviary each night at ca. 1900 hours and transported $(<400 \mathrm{~m})$ in a cloth bird bag to a separate laboratory for oxygen consumption trials. Birds were weighed before being placed into metabolic chambers and reweighed at the end of the trial the next morning on removal from the chamber. We report the average mass in subsequent analysis of oxygen consumption.

We measured the overnight oxygen consumption in postabsorptive individuals at thermoneutrality using an open-flow, push-through respirometry system (Sable Systems, Las Vegas,
NV; following Burness et al. 2010). Metabolic chambers containing individual birds were housed within a portable temperature-controlled cabinet (PTC-1, Sable Systems) maintained at $30^{\circ} \mathrm{C}$ (thermoneutrality; Marsh and Dawson 1982) using a temperature controller (Pelt-5, Sable Systems).

A typical recording sequence consisted of $15 \mathrm{~min}$ of measuring oxygen consumption from a chamber containing a bird followed by $5 \mathrm{~min}$ of baseline. This sequence continued overnight, alternating among each of the three chambers, from approximately 1945 hours each night to 0530 hours the next morning. Thus, when three birds were simultaneously tested, one 15-min measurement of each bird was obtained every hour for the entire sampling period. To ensure birds were postabsorptive, the first $4 \mathrm{~h}$ of $\mathrm{O}_{2}$ measurements were not considered, and thus ca. $1 \mathrm{~h}$ of oxygen consumption measurements were obtained per bird each night. RMR was considered to be the lowest stable 5-min period of oxygen consumption for each bird and was calculated using equation (10.1) from Lighton (2008). RMR was calculated for 42 individuals (24 males, 18 females). The precision of the respirometry system was $97 \%$, estimated by burning a known mass of methanol daily in a metabolic chamber and comparing it with theoretically predicted values.

\section{Statistical Analyses}

All statistical analyses were completed using Statistica, version 7.0 (StatSoft), and PASW Statistics 18.0 (SPSS). We used generalized linear models to directly compare bill and plumage color and physiological parameters between males and females. Analyses of color included Julian capture date as a covariate; analyses of physiological parameters included capture date and mass as covariates.

Following Garamszegi et al. (2009) and Garamszegi (2011), we use an information theoretic approach to infer relationships between color and physiological parameters. Our objective was to determine whether bill and/or plumage color predicted immunological (IgY, NAb) and physiological (H : L ratio, RMR) condition. Because of different function of the signals associated with ornamentation in each sex (see Murphy et al. 2009), males and females were analyzed separately. Likewise, because part of our objective was to test whether dynamic (bill) and static (plumage) ornaments signaled different information, we analyzed those ornaments separately. We assumed a priori that capture date and body mass were likely to influence some or all of our response variables, so we included them as predictor variables in each global model. For each response variable we tested 16 candidate linear regression models that included the following predictor variables either singly or in combination: date, mass, luminance, saturation, and hue or only an intercept. To avoid overfitting models, we included no more than one tristimulus color variable in any model. Thus, the 16 candidate models represent a subset of the possible models that would exist in a full-factorial design (i.e., all combinations of all five variables). We used Akaike Information Criterion-corrected (AICc) scores to assess models because among the models 
354 R. J. Kelly, T. G. Murphy, K. A. Tarvin, and G. Burness

Table 4: $95 \%$ confidence set of best-ranked regression models explaining variation in male bill color

\begin{tabular}{|c|c|c|c|c|c|c|}
\hline Model & $K$ & AICc & $\Delta \mathrm{AICc}$ & $W_{\mathrm{i}}$ & $\operatorname{Acc} W_{\mathrm{i}}$ & ER \\
\hline \multicolumn{7}{|l|}{ IgY: } \\
\hline Intercept only & 2 & -162.480 & .000 & .331 & .331 & $\ldots$ \\
\hline Date & 3 & -160.263 & 2.216 & .109 & .440 & 3.03 \\
\hline Luminance & 3 & -160.015 & 2.465 & .097 & .537 & 3.43 \\
\hline Saturation & 3 & -159.939 & 2.541 & .093 & .630 & 3.56 \\
\hline Mass & 3 & -159.910 & 2.570 & .092 & .721 & 3.61 \\
\hline Hue & 3 & -159.853 & 2.627 & .089 & .810 & 3.72 \\
\hline Luminance + date & 4 & -157.457 & 5.023 & .027 & .837 & 12.33 \\
\hline Hue + date & 4 & -157.456 & 5.024 & .027 & .864 & 12.33 \\
\hline Date + mass & 4 & -157.429 & 5.051 & .026 & .890 & 12.50 \\
\hline Saturation + date & 4 & -157.415 & 5.065 & .026 & .917 & 12.59 \\
\hline Luminance + mass & 4 & -157.148 & 5.331 & .023 & .940 & 14.38 \\
\hline \multicolumn{7}{|l|}{ NAb: } \\
\hline Date & 3 & -16.031 & .000 & .226 & .226 & $\ldots$ \\
\hline Intercept only & 2 & -15.725 & .306 & .194 & .420 & 1.17 \\
\hline Mass & 3 & -13.987 & 2.044 & .081 & .501 & 2.78 \\
\hline Hue & 3 & -13.940 & 2.091 & .079 & .581 & 2.84 \\
\hline Saturation & 3 & -13.558 & 2.473 & .066 & .647 & 3.44 \\
\hline Date + mass & 4 & -13.459 & 2.572 & .062 & .709 & 3.62 \\
\hline Luminance + date & 4 & -12.960 & 3.071 & .049 & .758 & 4.64 \\
\hline Saturation + date & 4 & -12.955 & 3.076 & .049 & .806 & 4.66 \\
\hline Hue + date & 4 & -12.909 & 3.122 & .047 & .854 & 4.76 \\
\hline Luminance & 3 & -12.894 & 3.136 & .047 & .901 & 4.80 \\
\hline Hue + mass & 4 & -11.826 & 4.205 & .028 & .929 & 8.19 \\
\hline \multicolumn{7}{|l|}{$\mathrm{H}: \mathrm{L}$ ratio: } \\
\hline Saturation & 3 & -52.437 & .000 & .395 & .395 & $\ldots$ \\
\hline Saturation + mass & 4 & -49.975 & 2.462 & .115 & .511 & 3.42 \\
\hline Saturation + date & 4 & -49.700 & 2.736 & .101 & .612 & 3.93 \\
\hline Luminance & 3 & -49.687 & 2.749 & .100 & .712 & 3.95 \\
\hline Intercept only & 2 & -49.512 & 2.925 & .092 & .803 & 4.32 \\
\hline Mass & 3 & -47.368 & 5.069 & .031 & .835 & 12.61 \\
\hline Mass + luminance & 4 & -47.276 & 5.160 & .030 & .865 & 13.20 \\
\hline Date & 3 & -47.001 & 5.436 & .026 & .891 & 15.15 \\
\hline Hue & 3 & -46.992 & 5.444 & .026 & .917 & 15.21 \\
\hline Saturation + mass + date & 5 & -46.987 & 5.449 & .026 & .943 & 15.25 \\
\hline \multicolumn{7}{|l|}{ RMR: } \\
\hline Mass & 3 & 62.581 & .000 & .418 & .418 & $\ldots$ \\
\hline Saturation + mass & 4 & 64.663 & 2.082 & .148 & .566 & 2.83 \\
\hline Hue + mass & 4 & 65.238 & 2.658 & .111 & .676 & 3.78 \\
\hline Date + mass & 4 & 65.256 & 2.675 & .110 & .786 & 3.81 \\
\hline Luminance + mass & 4 & 65.443 & 2.863 & .100 & .886 & 4.18 \\
\hline Hue + mass + date & 5 & 67.266 & 4.686 & .040 & .926 & 10.41 \\
\hline
\end{tabular}

Note. Abbreviations as in table 2.

tested, our sample sizes ( $n$ ) ranged from 18 to 28 and the number of parameters per model $(k)$ ranged from 2 to 5 ; thus $n / k<40$ for all analyses. We used full-model averaging to assess effects of the variables in the global model (Symonds and Moussalli 2011). We evaluated the importance of individual variables as predictors of physiological parameters based on the $\Delta \mathrm{AICc}$ and evidence ratio (ER) scores of models that included the variable of interest as well as the number of top models that the variable appeared in and the summed Akaike weight $(W)$ and the model-averaged slope $(\tilde{\bar{\beta}})$ with its associated variance $(\operatorname{Var}[\tilde{\bar{\beta}}])$ for that variable based on all models in the global set. We paid particular attention to the $\triangle \mathrm{AICc}$ and ER scores of models that included only an intercept. Intercept-only models with low values for these parameters (e.g., <2) indicate that 
Table 5: Full-model-averaged estimates for each variable in the global model predicting male bill color

\begin{tabular}{|c|c|c|c|}
\hline $\begin{array}{l}\text { Response and } \\
\text { predictor variables }\end{array}$ & $W$ & $\tilde{\bar{\beta}}$ & $\operatorname{Var}(\tilde{\bar{\beta}})$ \\
\hline \multicolumn{4}{|l|}{ IgY: } \\
\hline Intercept & & .1018 & 2.3596 \\
\hline Date & .232 & .0002 & $8.1 \times 10^{-6}$ \\
\hline Mass & .201 & .0006 & .0008 \\
\hline Luminance & .152 & .0106 & .1356 \\
\hline Saturation & .147 & -.0333 & 2.5155 \\
\hline Hue & .143 & $-4.6 \times 10^{-6}$ & $3.3 \times 10^{-6}$ \\
\hline \multicolumn{4}{|l|}{ NAb: } \\
\hline Intercept & $\ldots$ & -.0765 & $1,024.2883$ \\
\hline Date & .465 & .0202 & .0065 \\
\hline Mass & .243 & -.0514 & .2553 \\
\hline Luminance & .122 & -.1048 & 28.0158 \\
\hline Saturation & .149 & -1.9271 & $1,177.2817$ \\
\hline Hue & .165 & -.0029 & .0018 \\
\hline \multicolumn{4}{|l|}{ H : L ratio: } \\
\hline Intercept & ... & 4.1391 & 261.3802 \\
\hline Date & .202 & $4.8 \times 10^{-5}$ & .0012 \\
\hline Mass & .228 & .0136 & .0826 \\
\hline Luminance & .163 & .5194 & 19.3961 \\
\hline Saturation & .638 & -14.9671 & $1,928.8120$ \\
\hline Hue & .042 & $1.8 \times 10^{-6}$ & .0002 \\
\hline \multicolumn{4}{|l|}{ RMR: } \\
\hline Intercept & ... & -19.1368 & $30,498.9734$ \\
\hline Date & .211 & .0169 & .0901 \\
\hline Mass & .980 & 4.3884 & 38.5732 \\
\hline Luminance & .124 & -.4156 & 914.3803 \\
\hline Saturation & .181 & -13.8960 & $37,440.3627$ \\
\hline Hue & .160 & .0143 & .0611 \\
\hline
\end{tabular}

Note. Abbreviations as in table 3.

none of the models in the candidate set is particularly good at predicting the response variable.

\section{Results}

\section{Sex Differences}

Plumage of male goldfinches was significantly brighter and more saturated in the yellow region and had greater hue than that of females (table 1). Male bills were significantly brighter and had greater hue than those of females but did not differ in yellow saturation (table 1).

Males and females also differed in measures of immunity (table 1). When controlling for capture date, females had significantly higher NAb titers and IgY absorbance values than males, but males and females did not differ in the $\mathrm{H}: \mathrm{L}$ ratio. After accounting for differences in body mass, there was no significant sex difference in RMR (table 1).

\section{Bill Color}

In females, bill color was a strong predictor of IgY and the $\mathrm{H}: \mathrm{L}$ ratio but not other measures of immune function or RMR (fig. 1; tables 2, 3). The positive correlation between bill saturation and IgY was supported by the fact that saturation appeared in the top four models and by the fact that $W$ for saturation was 0.763 , which indicates a probability of $76.3 \%$ that it was a component of the true best model (tables 2, 3). Moreover, the ER indicated that the best model of the set, which included saturation and capture date, was 7.9 times better than the next best model that did not include saturation.

Female bill hue was negatively correlated with the $\mathrm{H}: \mathrm{L}$ ratio (tables 2, 3). The model containing only hue as a predictor variable was the best model in the set, and this model was 22 times better than the next best model that did not contain hue. Moreover, $W$ for hue was 0.91 . We also found some support for a positive relationship between female bill saturation and $\mathrm{NAb}(W=0.46)$, although the best model of the set, which included saturation and date, was only about 2.3 times better than a model that included only date, and the $\Delta \mathrm{AICc}$ score was 1.7 (tables 2, 3).

Mass was the most important predictor of RMR, but models including mass and one of the color variables had weak support ( $W$ for each color variable was approximately 0.12 ; table 3 ). However, the model containing only mass garnered approximately five times the evidence of models including mass and any one of the three color variables (table 2).

In males, bill color predicted the $\mathrm{H}: \mathrm{L}$ ratio but not other measures of immune function or RMR (fig. 1; tables 4, 5). Bill saturation was negatively correlated with the $\mathrm{H}: \mathrm{L}$ ratio, and saturation appeared in the top three models of the set. The best model of the set contained only saturation, and this model had four times the evidence of the highest-ranked model that did not contain saturation. Additionally, $W$ for saturation was 0.64 . However, we found little or no support for a correlation between bill color and IgY or NAb (tables 4,5 ). As with females, mass was the most important predictor of RMR in males, and we found weak support for correlations between color components and RMR when mass also was included as a predictor variable (tables 4,5 ).

\section{Plumage Color}

In contrast to bill color, female plumage color predicted NAb but was unrelated to IgY and the $\mathrm{H}: \mathrm{L}$ ratio (fig. 2; tables 6, $7)$. Throat hue was positively correlated with NAb: hue appeared in the top two models of the set, and $W$ for hue was 0.50 (tables 6,7 ). The top-ranked model contained hue, mass, and date and was 3.2 times better than the highest-ranking model that did not contain a color variable (date only; $\Delta \mathrm{AICc}=2.3$ ).

There was some support for a positive correlation between saturation and NAb as well $(W=0.22)$. We found no support for a relationship between female throat color and IgY or the $\mathrm{H}$ : $\mathrm{L}$ ratio; models including these variables had ERs that were 

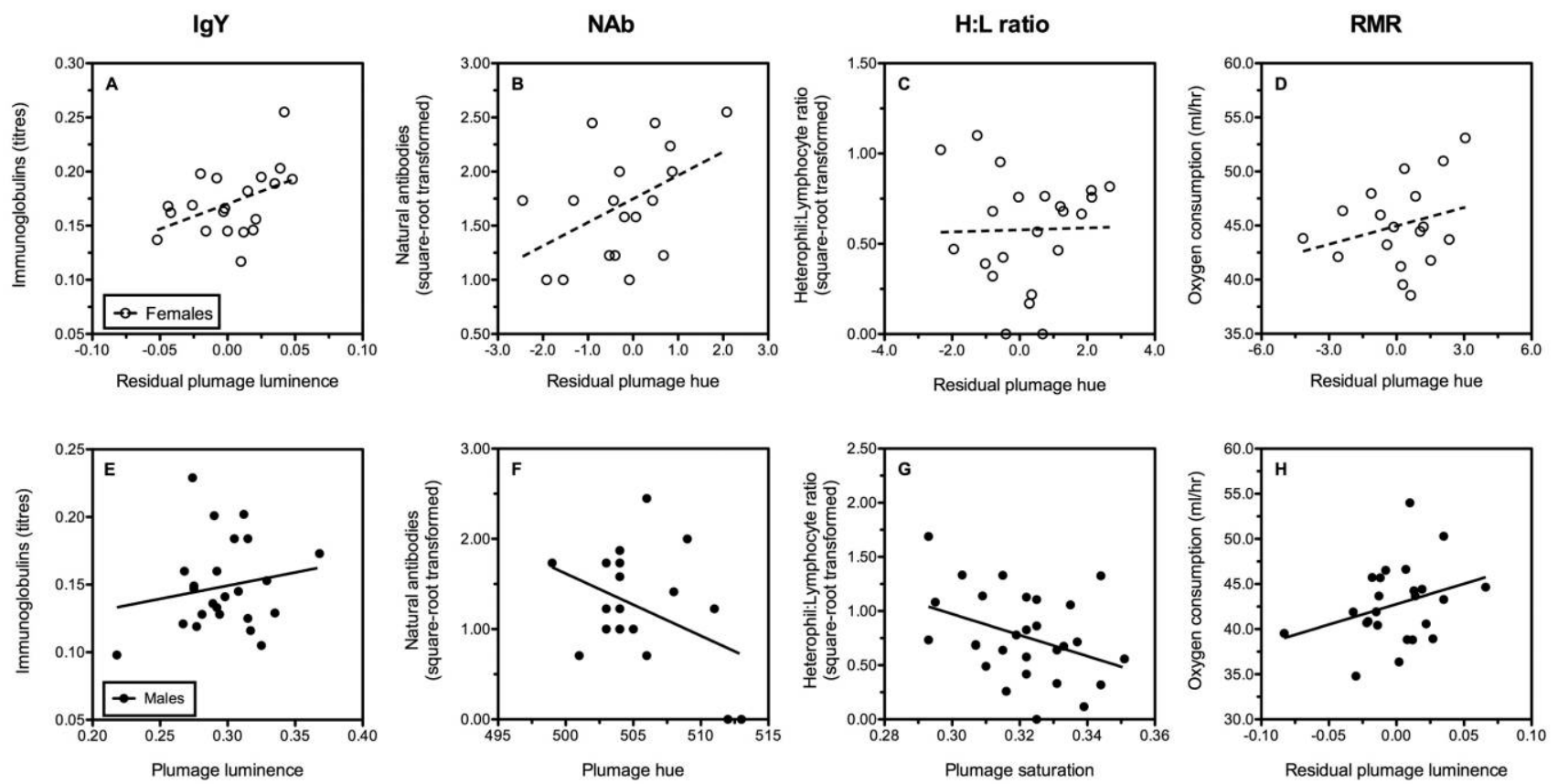

Figure 2. Plumage coloration in relation to physiology and immunology of female and male American goldfinches. The independent variable represents the best model of the set that contained a color variable. Note that the best model may have had similar support to a model containing only the intercept (see text for description of best models). Fitted lines are to aid in visual interpretation of patterns. Figures show residuals when the top model included two or more independent variables. Residuals in $A$ and $C$ controlled for the effect of date, in $B$ controlled for mass and date, and in $D$ and $H$ controlled for the effect of body mass on the color variable of interest. IgY = immunoglobulin $Y$; $\mathrm{NAb}=$ natural antibodies; $\mathrm{H}: \mathrm{L}$ ratio $=$ heterophil-to-lymphocyte ratio; $\mathrm{RMR}=$ resting metabolic rate.

either equal to or worse than a model that contained only the intercept (table 6).

In the analysis of RMR, mass appeared in each of the models that made up the $95 \%$ confidence set, and each color variable appeared in one of the top four models in the set. Of the three color variables, hue had the most support, and the top-ranked model (which contained only mass) had only 1.57 times the evidence of the model that contained both mass and hue. Thus, hue seems to be a predictor of female RMR such that females with high plumage hue had high RMR for their body mass (tables 6, 7; fig. 2).

Male throat color did not predict any of the immunological variables but was a good predictor of RMR (fig. 2; tables 8, 9). Regarding immunological variables, in all cases, even when a color variable had reasonable support relative to other variables in the global model, support for models containing a color variable was similar to that for a model containing only the intercept (i.e., $\triangle$ AICc scores were $<2.0$; tables 8,9 ). For RMR, luminance occurred in the top-ranked model (along with mass), and the $W$ score was 0.61 . Individuals with high luminance had relatively high RMR for their body mass. Even so, the top-ranked model garnered only twice the evidence of a model that included mass but no color variable $(\mathrm{ER}=$ 2.02; tables 8,9 ).

\section{Discussion}

In general, our findings are consistent with the hypothesis that carotenoid-based bill and plumage colors of American goldfinches function as condition-dependent signals. We showed that ornaments shared by the sexes are related to different aspects of immunity and physiology in males and females. We found that female bill color is strongly positively correlated with adaptive immunity (IgY) and that female plumage color (and to a lesser extent female bill color) is positively correlated with the innate immune system (NAb). However, male ornamentation was not related to either of these components of immunity, thus indicating that sex-specific mechanisms may mediate these signals. We additionally found that males and females with more colorful bills had a lower $\mathrm{H}: \mathrm{L}$ ratio and that plumage color in both sexes positively reflects RMR, although the specific component of color that correlated with measures of immunity and physiology varied with sex.

Taken together, our results indicate that dynamic bill and static plumage coloration differ in their potential to provide information about short-term versus long-term aspects of physiological condition. The highly variable bill color of both sexes is related to the $\mathrm{H}: \mathrm{L}$ ratio, which itself is known to fluctuate over the short term (on the order of hours to days) as heterophils increase and lymphocytes decrease in response to stress 
Table 6: 95\% confidence set of best-ranked regression models explaining variation in female throat color

\begin{tabular}{|c|c|c|c|c|c|c|}
\hline Model & $K$ & AICc & $\Delta \mathrm{AICc}$ & $W_{\mathrm{i}}$ & $\operatorname{Acc} W_{\mathrm{i}}$ & ER \\
\hline \multicolumn{7}{|l|}{ IgY: } \\
\hline Luminance + date & 4 & -137.448 & .000 & .175 & .175 & $\ldots$ \\
\hline Intercept only & 2 & -137.404 & .045 & .171 & .347 & 1.02 \\
\hline Luminance & 3 & -136.864 & .584 & .131 & .477 & 1.34 \\
\hline Luminance + mass + date & 5 & -136.803 & .645 & .127 & .604 & 1.38 \\
\hline Luminance + mass & 4 & -135.883 & 1.565 & .080 & .684 & 2.19 \\
\hline Date & 3 & -135.713 & 1.735 & .074 & .758 & 2.38 \\
\hline Mass & 3 & -135.247 & 2.202 & .058 & .816 & 3.01 \\
\hline Hue & 3 & -135.148 & 2.301 & .055 & .872 & 3.16 \\
\hline Saturation & 3 & -134.611 & 2.837 & .042 & .914 & 4.13 \\
\hline Date + mass & 4 & -133.063 & 4.386 & .020 & .934 & 8.96 \\
\hline \multicolumn{7}{|l|}{ NAb: } \\
\hline Hue + mass + date & 5 & -26.477 & .000 & .308 & .308 & $\ldots$ \\
\hline Hue + date & 4 & -25.259 & 1.218 & .168 & .476 & 1.84 \\
\hline Saturation + date & 4 & -24.464 & 2.013 & .113 & .589 & 2.74 \\
\hline Date & 3 & -24.156 & 2.321 & .097 & .685 & 3.19 \\
\hline Saturation + mass + date & 5 & -23.739 & 2.738 & .078 & .764 & 3.93 \\
\hline Mass & 3 & -23.040 & 3.437 & .055 & .819 & 5.58 \\
\hline Date + mass & 4 & -22.316 & 4.161 & .038 & .857 & 8.01 \\
\hline Intercept only & 2 & -22.188 & 4.289 & .036 & .894 & 8.54 \\
\hline Hue + mass & 4 & -21.046 & 5.431 & .020 & .914 & 15.11 \\
\hline Luminance + date & 4 & -20.893 & 5.584 & .019 & .933 & 16.32 \\
\hline \multicolumn{7}{|l|}{$\mathrm{H}: \mathrm{L}$ ratio: } \\
\hline Date & 3 & -52.156 & .000 & .260 & .260 & $\ldots$ \\
\hline Date + mass & 4 & -51.117 & 1.039 & .155 & .414 & 1.68 \\
\hline Intercept only & 2 & -50.428 & 1.728 & .110 & .524 & 2.37 \\
\hline Hue + date & 4 & -49.437 & 2.718 & .067 & .591 & 3.89 \\
\hline Luminance + date & 4 & -49.151 & 3.005 & .058 & .649 & 4.49 \\
\hline Saturation + date & 4 & -49.147 & 3.009 & .058 & .706 & 4.50 \\
\hline Saturation & 3 & -48.920 & 3.236 & .052 & .758 & 5.04 \\
\hline Hue & 3 & -48.521 & 3.635 & .042 & .800 & 6.16 \\
\hline Luminance & 3 & -48.266 & 3.889 & .037 & .837 & 6.99 \\
\hline Mass & 3 & -48.027 & 4.129 & .033 & .870 & 7.88 \\
\hline Luminance + mass + date & 5 & -47.870 & 4.286 & .030 & .901 & 8.52 \\
\hline Hue + mass + date & 5 & -47.850 & 4.306 & .030 & .931 & 8.61 \\
\hline \multicolumn{7}{|l|}{ RMR: } \\
\hline Mass & 3 & 37.030 & .000 & .338 & .338 & $\ldots$ \\
\hline Hue + mass & 4 & 37.934 & .903 & .215 & .554 & 1.57 \\
\hline Luminance + mass & 4 & 38.909 & 1.879 & .132 & .686 & 2.56 \\
\hline Saturation + mass & 4 & 39.052 & 2.021 & .123 & .809 & 2.75 \\
\hline Date + mass & 4 & 39.271 & 2.241 & .110 & .919 & 3.07 \\
\hline
\end{tabular}

Note. Abbreviations as in table 2.

(Davis et al. 2008). In contrast, plumage color in both sexes, which is stable over periods of time on the order of months, reflects RMR, which is likely consistent within individuals over time. Although RMR is known to be influenced by embryonic (Nilsson et al. 2011) and neonatal (Verhulst et al. 2006; Criscuolo et al. 2008) environments, significant repeatability in adult RMR has been reported over multiple years in the lab and field (Rønning et al. 2005; Broggi et al. 2009, reviewed by
Biro and Stamps 2010). If RMR is similarly relatively stable within adult goldfinches during the months before the nesting period, then our results may reflect a relationship between plumage color and RMR that persists several months after the prealternate moult. Furthermore, female plumage also reflects NAb levels. Constitutive innate NAb levels appear to vary little with environmental influences and are germ-line encoded and therefore likely reflect long-term (genetic) investment in innate 
Table 7: Full-model-averaged estimates for each variable in the global model predicting female throat color

\begin{tabular}{|c|c|c|c|}
\hline $\begin{array}{l}\text { Response and } \\
\text { predictor variables }\end{array}$ & $W$ & $\tilde{\bar{\beta}}$ & $\operatorname{Var}(\tilde{\bar{\beta}})$ \\
\hline \multicolumn{4}{|l|}{ IgY: } \\
\hline Intercept & $\ldots$ & -.0214 & 9.7076 \\
\hline Date & .435 & .0011 & $1.3 \times 10^{-5}$ \\
\hline Mass & .318 & .0036 & .0006 \\
\hline Luminance & .513 & .2341 & .5536 \\
\hline Saturation & .073 & .0024 & .4650 \\
\hline Hue & .091 & -.0002 & $3.0 \times 10^{-5}$ \\
\hline \multicolumn{4}{|l|}{ NAb: } \\
\hline Intercept & $\ldots$ & -64.2750 & $22,361.6500$ \\
\hline Date & .828 & .0524 & .0082 \\
\hline Mass & .536 & .1584 & .2484 \\
\hline Luminance & .052 & -.0394 & 18.3249 \\
\hline Saturation & .216 & 3.6149 & 376.4613 \\
\hline Hue & .505 & .1046 & .0778 \\
\hline \multicolumn{4}{|l|}{$\mathrm{H}: \mathrm{L}$ ratio: } \\
\hline Intercept & $\ldots$ & -2.4982 & $2,084.7220$ \\
\hline Date & .686 & .0181 & .0025 \\
\hline Mass & .317 & -.0332 & .0588 \\
\hline Luminance & .137 & -.1256 & 16.7791 \\
\hline Saturation & .154 & -.3001 & 85.2596 \\
\hline Hue & .153 & $2.8 \times 10^{-5}$ & .0070 \\
\hline \multicolumn{4}{|l|}{ RMR: } \\
\hline Intercept & $\ldots$ & -70.7990 & $143,776.1000$ \\
\hline Date & .191 & -.0179 & .0509 \\
\hline Mass & .999 & 4.3936 & 13.6359 \\
\hline Luminance & .158 & 4.5956 & $2,116.2750$ \\
\hline Saturation & .143 & 7.1490 & $6,727.6730$ \\
\hline Hue & .249 & .1177 & .5319 \\
\hline
\end{tabular}

Note. Abbreviations as in table 3.

immunity (Tieleman et al. 2005). Thus, our results suggest that in goldfinches, the speed at which bill and plumage signals change over time in general corresponds with the speed at which change occurs in the component of physiology that is reflected by each ornament. These results suggest that dynamic and static signals provide information about different temporal aspects of condition (the "multiple messages" hypothesis; Møller and Pomiankowski 1993).

Our finding that plumage color is positively correlated with RMR in both sexes is particularly interesting because we are unaware of any study that has correlated carotenoid coloration with metabolic rate. High RMR is thought to increase the capacity to perform well in challenging activities, and individuals with high RMR tend to have higher growth rates, have higher activity levels, and be more dominant (reviewed in Biro and Stamps 2010). This is likely to translate into a higher capacity to perform behavioral displays; provision young; and compete for food, mates, and nest sites, and receivers may benefit from identifying potential competitors or mates that have these qualities. On the other hand, it has been argued that individuals with high RMRs have higher activity rates and resulting oxidative damage (Wiersma et al. 2004). Accordingly, individuals with high RMRs would require more carotenoids to prevent oxidative damage. Given this likely trade-off, we expect individuals in good condition to be better able to sustain an elevated RMR (so as to increase the "capacity to engage in costly behaviour"; Biro and Stamps 2010, p. 657) while also producing colorful ornaments. Thus, male and female goldfinches with colorful plumage appear to be able to sustain the benefits of high RMR while also sustaining highly functional immune systems and colorful ornamentation.

Interpretation of the relationship between ornamentation and adaptive immunity as indicated by IgY levels is difficult because high antibody levels may reflect high immune capacity (via constituent antibodies that are ready to engage with pathogens) or an induced response to a specific infection agent (see Morales et al. 2004 for discussion of this dilemma). Thus, in the first case we would expect a positive correlation between an ornamental trait and IgY to represent a signal of high condition, as individuals with high levels of IgY should be highly immunocompetent. In contrast, in the second case a positive correlation would suggest that highly ornamented individuals were more susceptible to or more likely exposed to infection because they are likely to be fighting a specific infection at the time of blood sampling. To help discern between these possibilities, we can look at the distribution of IgY across individuals. Individuals within a population mounting an adaptive response to a current infection should have substantially higher antibody levels than individuals that are not engaged in fighting a particular infection. If IgY level indicates current infection, we would expect the distribution of antibody levels to be abruptly skewed because only some individuals in a population would be expected to be fighting an infection at a given time, and those individuals should have much higher levels of IgY than individuals that are not fighting an infection (see Butler et al. 2010; Ferreira et al. 2010). However, the observed distribution of IgY in goldfinches is monotonic (fig. $1 A, 1 E$ ), suggesting that our measure of IgY is a measure of constituent antibodies and reflects individual differences in immune preparedness.

Our observation that highly ornamented females have stronger immune systems (i.e., higher levels of both IgY and NAb) suggests that these females were in particularly good condition at the time of sampling (as bill color reflects condition-dependent $\operatorname{IgY}$ ) and during the lengthy moult period that occurred several weeks before sampling (as plumage color reflects genotype-dependent $\mathrm{NAb}$ ). This relationship is consistent with the hypothesis that there is a direct trade-off between use of carotenoids in ornamentation and immunity or oxidative stress management and that only high-quality individuals can successfully allocate carotenoids to both ornamentation and somatic maintenance. Alternatively, these results are consistent with the hypothesis that the degree of ornamentation and immune function each are dependent on the quality of subcellular and biochemical processes such that individuals in good condition (i.e., in which these processes function well) are simultaneously able to generate colorful carotenoid-based orna- 
Table 8: 95\% confidence set of best-ranked regression models explaining variation in male throat color

\begin{tabular}{|c|c|c|c|c|c|c|}
\hline Model & $K$ & $\mathrm{AICc}$ & $\Delta \mathrm{AICc}$ & $W_{\mathrm{i}}$ & $\operatorname{Acc} W_{\mathrm{i}}$ & ER \\
\hline \multicolumn{7}{|l|}{ IgY: } \\
\hline Intercept only & 2 & -162.480 & .000 & .303 & .303 & $\ldots$ \\
\hline Luminance & 3 & -160.598 & 1.882 & .118 & .422 & 2.56 \\
\hline Date & 3 & -160.263 & 2.216 & .100 & .522 & 3.03 \\
\hline Saturation & 3 & -160.146 & 2.334 & .094 & .616 & 3.21 \\
\hline Hue & 3 & -159.944 & 2.536 & .085 & .701 & 3.55 \\
\hline Mass & 3 & -159.910 & 2.570 & .084 & .785 & 3.61 \\
\hline Luminance + date & 4 & -158.814 & 3.666 & .048 & .834 & 6.25 \\
\hline Luminance + mass & 4 & -157.841 & 4.639 & .030 & .864 & 10.17 \\
\hline Saturation + date & 4 & -157.439 & 5.041 & .024 & .888 & 12.43 \\
\hline Date + mass & 4 & -157.429 & 5.051 & .024 & .912 & 12.50 \\
\hline Hue + date & 4 & -157.360 & 5.120 & .023 & .936 & 12.93 \\
\hline \multicolumn{7}{|l|}{ NAb: } \\
\hline Hue & 3 & -16.201 & .000 & .172 & .172 & $\ldots$ \\
\hline Date & 3 & -16.031 & .170 & .158 & .329 & 1.09 \\
\hline Saturation & 3 & -15.820 & .381 & .142 & .471 & 1.21 \\
\hline Intercept only & 2 & -15.725 & .476 & .135 & .606 & 1.27 \\
\hline Mass & 3 & -13.987 & 2.214 & .057 & .663 & 3.02 \\
\hline Hue + date & 4 & -13.862 & 2.339 & .053 & .716 & 3.22 \\
\hline Hue + mass & 4 & -13.620 & 2.581 & .047 & .763 & 3.63 \\
\hline Saturation + mass & 4 & -13.522 & 2.679 & .045 & .808 & 3.82 \\
\hline Date + mass & 4 & -13.459 & 2.742 & .044 & .852 & 3.94 \\
\hline Saturation + date & 4 & -13.400 & 2.801 & .042 & .894 & 4.06 \\
\hline Luminance & 3 & -12.922 & 3.278 & .033 & .927 & 5.15 \\
\hline \multicolumn{7}{|l|}{$\mathrm{H}$ : L ratio: } \\
\hline Saturation & 3 & -51.351 & .000 & .292 & .292 & $\ldots$ \\
\hline Saturation + date & 4 & -49.556 & 1.796 & .119 & .412 & 2.45 \\
\hline Intercept only & 2 & -49.512 & 1.839 & .117 & .528 & 2.51 \\
\hline Hue & 3 & -49.374 & 1.977 & .109 & .637 & 2.69 \\
\hline Saturation + mass & 4 & -49.181 & 2.171 & .099 & .736 & 2.96 \\
\hline Luminance & 3 & -47.502 & 3.850 & .043 & .778 & 6.85 \\
\hline Mass & 3 & -47.368 & 3.983 & .040 & .818 & 7.33 \\
\hline Hue + mass & 4 & -47.286 & 4.065 & .038 & .857 & 7.63 \\
\hline Date & 3 & -47.001 & 4.350 & .033 & .890 & 8.80 \\
\hline Saturation + mass + date & 5 & -46.963 & 4.388 & .033 & .922 & 8.97 \\
\hline \multicolumn{7}{|l|}{ RMR: } \\
\hline Luminance + mass & 4 & 61.176 & .000 & .402 & .402 & $\ldots$ \\
\hline Mass & 3 & 62.581 & 1.405 & .199 & .601 & 2.02 \\
\hline Luminance + mass + date & 5 & 62.613 & 1.437 & .196 & .796 & 2.05 \\
\hline Saturation + mass & 4 & 64.951 & 3.775 & .061 & .857 & 6.60 \\
\hline Date + mass & 4 & 65.256 & 4.080 & .052 & .909 & 7.69 \\
\hline Hue + mass & 4 & 65.262 & 4.086 & .052 & .962 & 7.71 \\
\hline Saturation + mass + date & 5 & 68.158 & 6.982 & .012 & .974 & 32.82 \\
\hline
\end{tabular}

Note. Abbreviations as in table 2.

ments, sustain highly functional immune systems, and deal with oxidative stress (Hill 2011). Whether or not direct trade-offs are involved, the patterns we observed are consistent with the hypothesis that carotenoid-based ornaments signal immunological capacity in female goldfinches. The reasons that such ornaments do not act as a similar signal of immunological capacity in male goldfinches is not clear, especially given the links between carotenoid-based signals and aspects of immunity in other species (e.g., Aguilera and Amat 2007; Baeta et al. 2008; Dunn et al. 2010).

There is good reason to expect goldfinches to make use of reliable signals of quality in both sexual and competitive con- 
Table 9: Full-model-averaged estimates for each variable in the global model predicting male throat color

\begin{tabular}{|c|c|c|c|}
\hline $\begin{array}{l}\text { Response and } \\
\text { predictor variables }\end{array}$ & $W$ & $\tilde{\bar{\beta}}$ & $\operatorname{Var}(\tilde{\bar{\beta}})$ \\
\hline \multicolumn{4}{|l|}{ IgY: } \\
\hline Intercept & $\ldots$ & .1247 & 5.1162 \\
\hline Date & .241 & .0002 & $1.0 \times 10^{-5}$ \\
\hline Mass & .202 & .0007 & .0008 \\
\hline Luminance & .208 & .0465 & .2955 \\
\hline Saturation & .147 & -.0318 & .7763 \\
\hline Hue & .134 & -.0001 & $1.3 \times 10^{-5}$ \\
\hline \multicolumn{4}{|l|}{ NAb: } \\
\hline Intercept & $\ldots$ & 8.9741 & $3,014.1640$ \\
\hline Date & .356 & .0138 & .0056 \\
\hline Mass & .233 & -.0466 & .2396 \\
\hline Luminance & .086 & -.1283 & 46.7869 \\
\hline Saturation & .238 & -2.9058 & 368.9960 \\
\hline Hue & .283 & -.0177 & .0096 \\
\hline \multicolumn{4}{|l|}{$\mathrm{H}: \mathrm{L}$ ratio: } \\
\hline Intercept & $\ldots$ & 6.4036 & 987.5518 \\
\hline Date & .250 & -.0025 & .0018 \\
\hline Mass & .244 & .0187 & .0911 \\
\hline Luminance & .069 & -.1235 & 14.2329 \\
\hline Saturation & .543 & -5.7172 & 394.3418 \\
\hline Hue & .188 & -.0069 & .0032 \\
\hline \multicolumn{4}{|l|}{ RMR: } \\
\hline Intercept & $\ldots$ & -21.5376 & $28,906.6800$ \\
\hline Date & .276 & .0326 & .0981 \\
\hline Mass & .987 & 4.2292 & 34.9743 \\
\hline Luminance & .607 & 30.3481 & $8,541.9210$ \\
\hline Saturation & .074 & -2.2339 & $3,941.7780$ \\
\hline Hue & .064 & -.0056 & .0749 \\
\hline
\end{tabular}

Note. Abbreviations as in table 3.

texts. Both males and females forage in flocks that vary in composition throughout the year (McGraw and Middleton 2009) and are likely to routinely engage in competitive interactions with both familiar and unfamiliar individuals. Furthermore, both sexes contribute substantially to parental care (McGraw and Middleton 2009), and as a result, both sexes may benefit from assessing quality of potential mates (Johnstone et al. 1996; Amundsen 2000). In our earlier work, we found that female (but not male) bill color functions as a signal to other females during competition for nonsexual resources such as food (Murphy et al. 2009) but that bill color does not appear to be used in mate choice by either sex (Murphy et al. 2009; T. G. Murphy and K. A. Tarvin, unpublished data). Thus, the finding of this study that female bill color is positively correlated with immune function suggests that immunological capacity plays an important role in determining a female's ability to invest in competitive interactions or that perhaps bill color and immunity both represent general measures of condition. Our findings also indicate that both male plumage and female plumage have the potential to function as a signal of quality and that both sexes may be assessed during mate choice (see MacDougall and Montgomerie 2003). Several studies have shown that male goldfinch plumage color signals general aspects of nutritional and health status (e.g., McGraw and Hill 2000, 2001; Rosen and Tarvin 2006; Hill et al. 2009) and that colorful male plumage is preferred by females (Johnson et al. 1993). Future work is necessary to assess the signaling role of female plumage.

In this study, we identify specific components of immunological and physiological condition that are signaled by both male and female ornaments and show that dynamic and static ornaments signal components of condition that differ in the timescale over which they vary. Our results suggest that ornaments can have a sex-specific functional role in social and sexual interactions even when those traits are expressed similarly in the sexes. Our work thus raises questions about how the social and sexual contexts of signals influence their information content.

\section{Acknowledgments}

We thank Bob Montgomerie for intellectual support and the staff of the Queen's University Biology Station for logistic support. Funding for research and equipment was provided by the Natural Sciences and Engineering Research Council (Canada), the Canadian Foundation for Innovation, and the Ontario Ministry of Innovation to G.B.; National Science Foundation International Research Fellowship Program and Americas Program (0700953) to T.G.M.; and Oberlin College, the Jakus Fund of the Oberlin Biology Department, and the A. W. Mellon Foundation. Lisha Berzins provided assistance with immune system assays, and Malcolm Rosenthal provided assistance with fieldwork. Bob Montgomerie and Joe Nocera provided helpful comments on an early draft of the Akaike Information Criterion analysis.

\section{Literature Cited}

Aguilera E. and J.A. Amat. 2007. Carotenoids, immune response and the expression of sexual ornaments in male greenfinches (Carduelis chloris). Naturwissenschaften 94:895-902.

Alvarez F., C. Sanchez, and S. Angulo. 2005. The frontal shield of the moorhen: sex differences and relationship with body condition. Ethol Ecol Evol 17:135-148.

Amundsen T. 2000. Why are female birds ornamented? Trends Ecol Evol 15:149-155.

Andersson M. 1994. Sexual selection. Princeton University Press, Princeton, NJ.

Ardia D.R., H.K. Parmentier, and L.A. Vogel. 2011. The role of constraints and limitation in driving individual variation in immune response. Funct Ecol 25:61-73.

Baeta R., B. Faivre, S. Motreuil, M. Gaillard, and J. Moreau. 2008. Carotenoid trade-off between parasitic resistance and sexual display: an experimental study in the blackbird (Turdus merula). Proc R Soc B 275:427-434. 
Biro P.A. and J.A. Stamps. 2010. Do consistent individual differences in metabolic rate promote consistent individual differences in behavior? Trends Ecol Evol 25:653-659.

Bourgeon S., J. Martinez, F. Criscuolo, Y. Le Maho, and T. Raclot. 2006. Fasting-induced changes of immunological and stress indicators in breeding female eiders. Gen Comp Endocrinol 147:336-342.

Broggi J., E. Hohtola, K. Koivula, M. Orell, and J.-Å. Nilsson. 2009. Long-term repeatability of winter basal metabolic rate and mass in a wild passerine. Funct Ecol 23:768-773.

Buehler D.M., N. Bhola, D. Barjaktarov, W. Goymann, I. Schwabl, B.I. Tieleman, and T. Piersma. 2008. Constitutive immune function responds more slowly to handling stress than corticosterone in a shorebird. Physiol Biochem Zool 81:673-681.

Burness G., C. Armstrong, T. Fee, and E. Tilman-Schindel. 2010. Is there an energetic based trade-off between thermoregulation and the acute phase response in zebra finches? J Exp Biol 213:1386-1394.

Butler M.W., L.L. Leppert, and A.M. Dufty Jr. 2010. Effects of small increases in corticosterone levels on morphology, immune function, and feather development. Physiol Biochem Zool 83:78-86.

Chew B.P., B.D. Mathison, M.G. Hayek, S. Massimino, G.A. Reinhart, and J.S. Park. 2011. Dietary astaxanthin enhances immune response in dogs. Vet Immunol Immunopathol 140: 199-206.

Chew B.P. and J.S. Park. 2004. Carotenoid action on the immune response. J Nutr 134:257S-261S.

Clotfelter E.D., D.R. Ardia, and K.J. McGraw. 2007. Red fish, blue fish: trade-offs between pigmentation and immunity in Betta splendens. Behav Ecol 18:1139-1145.

Clutton-Brock T. 2009. Sexual selection in females. Anim Behav $77: 3-11$.

Costantini D. and A.P. Møller. 2008. Carotenoids are minor antioxidants for birds. Funct Ecol 22:367-370.

Criscuolo F., P. Monaghan, L. Nasir, and N.B. Metcalfe. 2008. Early nutrition and phenotypic development: "catch-up" growth leads to elevated metabolic rate in adulthood. Proc R Soc B 275:1565-1570.

Davis A.K. 2005. Effect of handling time and repeated sampling on avian white blood cell counts. J Field Ornithol 76:334338.

Davis A.K., D.L. Maney, and J.C. Maerz. 2008. The use of leukocyte profiles to measure stress in vertebrates: a review for ecologists. Funct Ecol 22:760-772.

Demas G.E., D.A. Zysling, B.R. Beechler, M.P. Muehlenbein, and S.S. French. 2011. Beyond phytohaemagglutinin: assessing vertebrate immune function across ecological contexts. J Anim Ecol 80:710-730.

Doucet S.M. and R. Montgomerie. 2003. Structural plumage color and parasites in satin bowerbirds Ptilonorhynchus violaceus: implications for sexual selection. J Avian Biol 34:237242.

Dufva R. and K. Allander. 1995. Intraspecific variation in plum- age coloration reflects immune response in great tit (Parus major) males. Funct Ecol 9:785-789.

Dunn P.O., J.C. Garvin, L.A. Whittingham, C.R. Freeman-Gallant, and D. Hasselquist. 2010. Carotenoid and melaninbased ornaments signal similar aspects of male quality in two populations of the common yellowthroat. Funct Ecol 24:149158.

Faivre B., M. Preault, F. Salvadori, M. Thery, M. Gaillard, and F. Cezilly. 2003. Bill colour and immunocompetence in the European blackbird. Anim Behav 65:1125-1131.

Ferreira H.L., J.F. Pirlot, B. Kaspers, S. Kothlow, T. van den Berg, and B. Larnbrecht. 2010. Development of specific enzyme-linked immunosorbent assays to evaluate the duck immune response after experimental infection with $\mathrm{H} 5 \mathrm{~N} 1$ and H7N1 low pathogenic avian influenza viruses. Avian Dis 54:660-667.

Garamszegi L.Z. 2011. Information-theoretic approaches to statistical analysis in behavioral ecology: an introduction. Behav Ecol Sociobiol 65:1-11.

Garamszegi L.Z., S. Calhim, N. Dochtermann, G. Hegyi, P.L. Hurd, C. Jørgensen, N. Kutsukake, et al. 2009. Changing philosophies and tools for statistical inferences in behavioral ecology. Behav Ecol 20:1363-1375.

Hanssen S.A., I. Folstad, and K.E. Erikstad. 2006. White plumage reflects individual quality in female eiders. Anim Behav 71:337-343.

Heinsohn R., S. Legge, and J.A. Endler. 2005. Extreme reversed sexual dichromatism in a bird without sex role reversal. Science 309:617-619.

Hill G.E. 2011. Condition-dependent traits as signals of the functionality of vital cellular processes. Ecol Lett 14:625-634.

Hill G.E., W.R. Hood, and K. Huggins. 2009. A multifactorial test of the effects of carotenoid access, food intake and parasite load on the production of ornamental feathers and bill coloration in American goldfinches. J Exp Biol 212:1225-1233.

Hõrak P., M. Zilmer, L. Saks, I. Ots, U. Karu, and K. Zilmer. 2006. Antioxidant protection, carotenoids, and the costs of immune challenge in greenfinches. J Exp Biol 209:4329-4338.

Johnson K., R. Dalton, and N. Burley. 1993. Preferences of female American goldfinches (Carduelis tristis) for natural and artificial male traits. Behav Ecol 4:138-143.

Johnstone R.A., J.D. Reynolds, and J.C. Deutsch. 1996. Mutual mate choice and sex differences in choosiness. Evolution 50: 1382-1391.

LeBas N.R. 2006. Female finery is not for males. Trends Ecol Evol 21:170-173.

Lighton J.R.B. 2008. Measuring metabolic rates: a manual for scientists. Oxford University Press, Toronto.

Lopez G., J. Figuerola, and R. Soriguer. 2008. Carotenoid-based masks in the European goldfinch Carduelis carduelis reflect different information in males and females. Ardea 96:233-242.

Lozano G.A. 1994. Carotenoids, parasites, and sexual selection. Oikos 70:309-311.

MacDougall A.K. and R. Montgomerie. 2003. Assortative mating by carotenoid-based plumage colour: a quality indicator 
in American goldfinches, Carduelis tristis. Naturwissenschaften 90:464-467.

Maney D.L., A.K. Davis, C.T. Goode, A. Reid, and C. Showalter. 2008. Carotenoid-based plumage coloration predicts leukocyte parameters during the breeding season in northern cardinals (Cardinalis cardinalis). Ethology 114:369-380.

Marsh R.L. and W.R. Dawson. 1982. Substrate metabolism in seasonally acclimatized American goldfinches. Am J Physiol 242:R563-R569.

Martín J. and P. López. 2009. Multiple color signals may reveal multiple messages in male Schreiber's green lizards (Lecerta schreiberi). Behav Ecol Sociobiol 63:1743-1755.

Martin L.B., II, Z.M. Weil, and R.J. Nelson. 2007. Immune defense and reproductive pace of life in Peromyscus mice. Ecology 88:2516-2528.

Matson K.D., R.E. Ricklefs, and K.C. Klasing. 2005. A hemolysis-hemagglutination assay for characterizing constitutive innate humoral immunity in wild and domestic birds. Dev Comp Immunol 29:275-286.

McGraw K.J. and D.R. Ardia. 2003. Carotenoids, immunocompetence, and the information content of sexual colors: an experimental test. Am Nat 162:704-712.

McGraw K.J. and G.E. Hill. 2000. Differential effects of endoparasitism on the expression of carotenoid- and melaninbased ornamental coloration. Proc R Soc B 267:1525-1531. . 2001. Carotenoid access and intraspecific variation in plumage pigmentation in male American goldfinches (Carduelis tristis) and northern cardinals (Cardinalis cardinalis). Funct Ecol 15:732-739.

McGraw K.J. and A.L. Middleton. 2009. American goldfinch (Spinus tristis). In A. Poole, ed. The birds of North America online. Cornell Lab of Ornithology, Ithaca, NY. http://bna .birds.cornell.edu/bna/species/080, doi:10.2173/bna.80.

Møller A.P., C. Biard, J.D. Blount, D.C. Houston, P. Ninni, N. Saino, and P.F. Surai. 2000. Carotenoid-dependent signals: indicators of foraging efficiency, immunocompetence or detoxification ability? Avian Poult Biol Rev 11:137-159.

Møller A.P. and A. Pomiankowski. 1993. Why have birds got multiple sexual ornaments. Behav Ecol Sociobiol 32:167-176.

Montgomerie R. 2006. Analyzing colors. Pp. 90-147 in G.E. Hill and K.J. McGraw, eds. Bird coloration. Vol. 1. Harvard University Press, Cambridge, MA.

- 2008. RCLR. Version 0.9.28. Queen's University, Kingston, Ontario.

Morales J., J. Moreno, S. Merino, G. Tomás, J. Martínez, and L.Z. Garamszegi. 2004. Associations between immune parameters, parasitism, and stress in breeding pied flycatcher (Ficedula hypoleuca) females. Can J Zool 82:1484-1492.

Müller C., S. Jenni-Eierman, and L. Jenni. 2011. Heterophils/ lymphocytes-ratio and circulating corticosterone do not indicate the same stress imposed on Eurasian kestrel nestlings. Funct Ecol 25:566-576.

Murphy T.G. 2006. Predator-elicited visual signal: why the turquoise-browed motmot wag-displays its racketed tail. Behav Ecol 17:547-553.

- 2007. Racketed tail of the male and female turquoise- browed motmot: male but not female tail length correlates with pairing success, performance, and reproductive success. Behav Ecol Sociobiol 61:911-918.

Murphy T.G., M.F. Rosenthal, R. Montgomerie, and K.A. Tarvin. 2009. Female American goldfinches use carotenoidbased bill coloration to signal status. Behav Ecol 20:13481355.

Nilsson J.F., M. Tobler, J.-Å. Nilsson, and M.I. Sandell. 2011. Long-lasting consequences of elevated yolk testosterone for metabolism in the zebra finch. Physiol Biochem Zool 84: 287-291.

Norris K. and M.R. Evans. 2000. Ecological immunology: life history trade-offs and immune defense in birds. Behav Ecol 11:19-26.

Nunn C.L., P. Lindenfors, E.R. Pursall, and J. Rolff. 2009. On sexual dimorphism in immune function. Philos Trans $\mathrm{R}$ Soc B 364:61-69.

Ochsenbein A.F. and R.M. Zinkernagel. 2000. Natural antibodies and complement link innate and acquired immunity. Immunol Today 21:624-630.

Pap P.L., G.A. Czirják, C.I. Vágási, Z. Barta, and D. Hasselquist. 2010. Sexual dimorphism in immune function changes during the annual cycle in house sparrows. Naturwissenschaften 97:891-901.

Pärn H., J.T. Lifjeld, and T. Amundsen. 2005. Female throat ornamentation does not reflect cell-mediated immune response in bluethroats Luscinia s. svecica. Oecologia 146:496504.

Pyle P. 1997. Identification guide to North American birds. Pt. I. Slate Creek, Bolinas, CA.

Rao A.V. and L.G. Rao. 2007. Carotenoids and human health. Pharmacol Res 55:207-216.

Rønning B., B. Moe, and C. Bech. 2005. Long-term repeatability makes basal metabolic rate a likely heritable trait in the zebra finch Taeniopygia guttata. J Exp Biol 208:4663-4669.

Rosen R.F. and K.A. Tarvin. 2006. Sexual signals of the male American goldfinch. Ethology 112:1008-1019.

Roulin A., C. Dijkstra, C. Riols, and A.-L. Ducrest. 2001a. Female- and male-specific signals of quality in the barn owl. J Evol Biol 14:255-266.

Roulin A., C. Riols, C. Dijkstra, and A.-L. Ducrest. 2001b. Female plumage spottiness signals parasite resistance in the barn owl (Tyto alba). Behav Ecol 12:103-110.

Saks L., K. McGraw, and P. Hõrak. 2003. How feather colour reflects its carotenoid content. Funct Ecol 17:555-561.

Symonds M.R.E. and A. Moussalli. 2011. A brief guide to model selection, multimodel inference and model averaging in behavioral ecology using Akaike's information criterion. Behav Ecol Sociobiol 65:13-21.

Tieleman B.I., T.H. Dijkstra, K.C. Klasing, G.H. Visser, and J.B. Williams. 2008. Effects of experimentally increased costs of activity during reproduction on parental investment and selfmaintenance in tropical house wrens. Behav Ecol 19:949959.

Tieleman B.I., J.B. Williams, R.E. Ricklefs, and K.C. Klasing. 2005. Constitutive innate immunity is a component of the 
pace-of-life syndrome in tropical birds. Proc R Soc B 272: 1715-1720.

Van de Crommenacker J., N.P.C. Horrocks, M.A. Versteegh, J. Komdeur, B.I. Tieleman, and K.D. Matson. 2010. Effects of immune supplementation and immune challenge on oxidative status and physiology in a model bird: implications for ecologists. J Exp Biol 213:3527-3535.

Verhulst S., M. Holveck, and K. Riebel. 2006. Long-term effects of manipulated natal brood size on metabolic rate in zebra finches. Biol Lett 2:478-480.

Wiersma P., A. Muñoz-Garcia, A. Walker, and J.B. Williams. 2007. Tropical birds have a slow pace of life. Proc Natl Acad Sci USA 104:9340-9345.

Wiersma P., C. Selman, J.R. Speakman, and S. Verhulst. 2004. Birds sacrifice oxidative protection for reproduction. Proc R Soc B 271(suppl.):S360-S363. 